\title{
Is nuclear fission a sustainable source of energy?
}

\author{
Matthias Englert, Lindsay Krall, and Rodney C. Ewing
}

During this century, humankind must deal with increasing demand for energy and the growing impact of burning fossil fuels. Nuclear power, which presently produces $14 \%$ of global electricity, is a low-carbon-emissions alternative. However, the sustainability of nuclear power depends on the amounts of uranium and thorium available, the economics of their recovery from ore deposits, and the safety and security of nuclear materials. Unlike combustion of hydrocarbons, which determines the amount of fuel needed for a given amount of energy, nuclear reactions can create additional fissile isotopes. Hence, the choice of nuclear fuel cycle profoundly affects the size of the nuclear resource, as well as nuclear waste management and the risk of proliferation of nuclear weapons. We argue that uranium resources, identified and yet to be discovered, could sustain increases in nuclear power generation by a factor of two or three through the end of this century, even without advanced closed-fuel-cycle technologies.

\section{Introduction}

Nuclear power could ease the transition to a more sustainable energy economy, if it can substitute for enough fossil fuel. Key to evaluating the potential of nuclear energy to meet future demands are the amounts of uranium and thorium economically available. Estimates are necessarily speculative, as they require knowledge of the abundance, quality, and distribution of the metals in ore deposits, as well as the costs of extraction (mining and milling). In addition, the potential energy production is profoundly affected by the choice of nuclear fuel cycle.

For the open fuel cycle, which entails direct disposal of used nuclear fuel, nuclear power capacity depends directly on the amounts of uranium and thorium available. Today's estimates of uranium resources have identified 6300 kilotonnes $(\mathrm{kt})$ (at a price of up to US\$260/kg of uranium), which would sustain the current demand of roughly $63 \mathrm{kt} / \mathrm{yr}$ until the end of this century. If nuclear power generation were to double or triple by the end of the century, the currently estimated 10,400 kt of undiscovered resources would have to be brought into production as well.

The open fuel cycle uses less than $1 \%$ of the energy content of the uranium fuel. In contrast, the closed fuel cycle, with reprocessing to reclaim fissile nuclides such as plutonium, can extend the uranium resource by breeding fissile ${ }^{239} \mathrm{Pu}$ from the much more abundant ${ }^{238} \mathrm{U}$ or fissile ${ }^{233} \mathrm{U}$ from ${ }^{232} \mathrm{Th}$. The fully closed fuel cycle requires advanced processing technologies that can efficiently separate fissile actinides, as well as the development and use of fast reactors that employ higher-energy neutrons that fission actinides more efficiently. Such fully closed systems could use as much as $70 \%$ of the energy content of the nuclear fuel. In addition to efficiency, however, the sustainability of nuclear power also depends on how each type of fuel cycle affects the risk of nuclear proliferation and the disposal of nuclear waste.

\section{Uranium as a reactor fuel}

Mined uranium ore, mainly $\mathrm{UO}_{2}$ and $\mathrm{USiO}_{4}$, is chemically concentrated in the form of so-called yellowcake $\left(\mathrm{U}_{3} \mathrm{O}_{8}\right)$. This natural uranium produced from mines contains only $0.72 \%$ fissile ${ }^{235} \mathrm{U}$; the remainder is ${ }^{238} \mathrm{U}$. It can be directly used only in reactors that use heavy water ( $>99 \%$ deuterium) or graphite as a moderator to slow the high-energy neutrons released in a fission event. For use in light-water-moderated reactors (LWRs), yellowcake is converted to gaseous uranium hexafluoride $\left(\mathrm{UF}_{6}\right)$ and enriched, typically to $3.5-5 \%{ }^{235} \mathrm{U}$, by either centrifuge or gaseous-diffusion technologies. In most of today's reactors, the final fuel is $\mathrm{UO}_{2}$, although some use metallic uranium. Some advanced designs envision the use of ceramic or molten-salt uranium fuels. 
Most nuclear power plants today use the uranium/plutonium fuel cycle. The world's 440 or so reactors produce $375 \mathrm{GW}$ of electricity $\left(\mathrm{GW}_{\mathrm{e}}\right),{ }^{1}$ about $14 \%$ of the global supply. ${ }^{2}$ Most reactors are LWRs. A typical core contains $100 \mathrm{t}$ of fuel, in the form of ${ }^{235} \mathrm{U}$-enriched $\mathrm{UO}_{2}$, and generates approximately 20-30 t of spent fuel per year. Together, the world's reactors require the production of approximately $63 \mathrm{kt}$ of natural uranium each year. ${ }^{3}$

\section{Uranium resource estimates}

Every two years, the International Atomic Energy Agency (IAEA) and the Nuclear Energy Agency of the Organization for Economic Co-operation and Development jointly publish global estimates of the uranium available in various categories of resources in the "Red Book"4 (Table I), based on mining-company estimates. In 2009, 4000 kt of uranium was classified as being in reasonably assured resources (RAR), for which there is direct geological evidence. Knowledge of existing deposits leads with high confidence to the location and size of an additional $2300 \mathrm{kt}$ in inferred resources (IR). Together, these two classes constitute identified resources, and their distribution is shown in Figure 1. The world's largest known deposit, Olympic Dam in South Australia, is estimated to have $1447 \mathrm{kt}$ of uranium in RAR

Note: Data from the International Atomic Energy Agency (IAEA) "Red Book." ${ }^{6}$ As of June 2011, yellowcake $\left(\mathrm{U}_{3} \mathrm{O}_{8}\right)$ was priced at US $\$ 56 / \mathrm{lb}$.

Table I. Classification and estimates of uranium resources.

\begin{tabular}{|l|c|c|c|c|}
\hline $\begin{array}{c}\text { Commodity price for } \\
\text { extraction feasibility } \\
\text { (US\$//b of } \mathbf{U}_{\mathbf{3}} \mathbf{O}_{\mathbf{8}} \text { ) }\end{array}$ & $\begin{array}{c}\text { Reasonably } \\
\text { assured (kt) }\end{array}$ & Inferred (kt) & Prognosticated (kt) & Speculative (kt) \\
\hline$<40$ & 570 & 226 & & \\
\hline$<80$ & 2516 & 1226 & 1702 & \\
\hline$<130$ & 3525 & 1879 & 2815 & 3738 \\
\hline$<260$ & 4004 & 2302 & 2905 & 3902 \\
\hline Unassigned & & & & 3594 \\
\hline
\end{tabular}

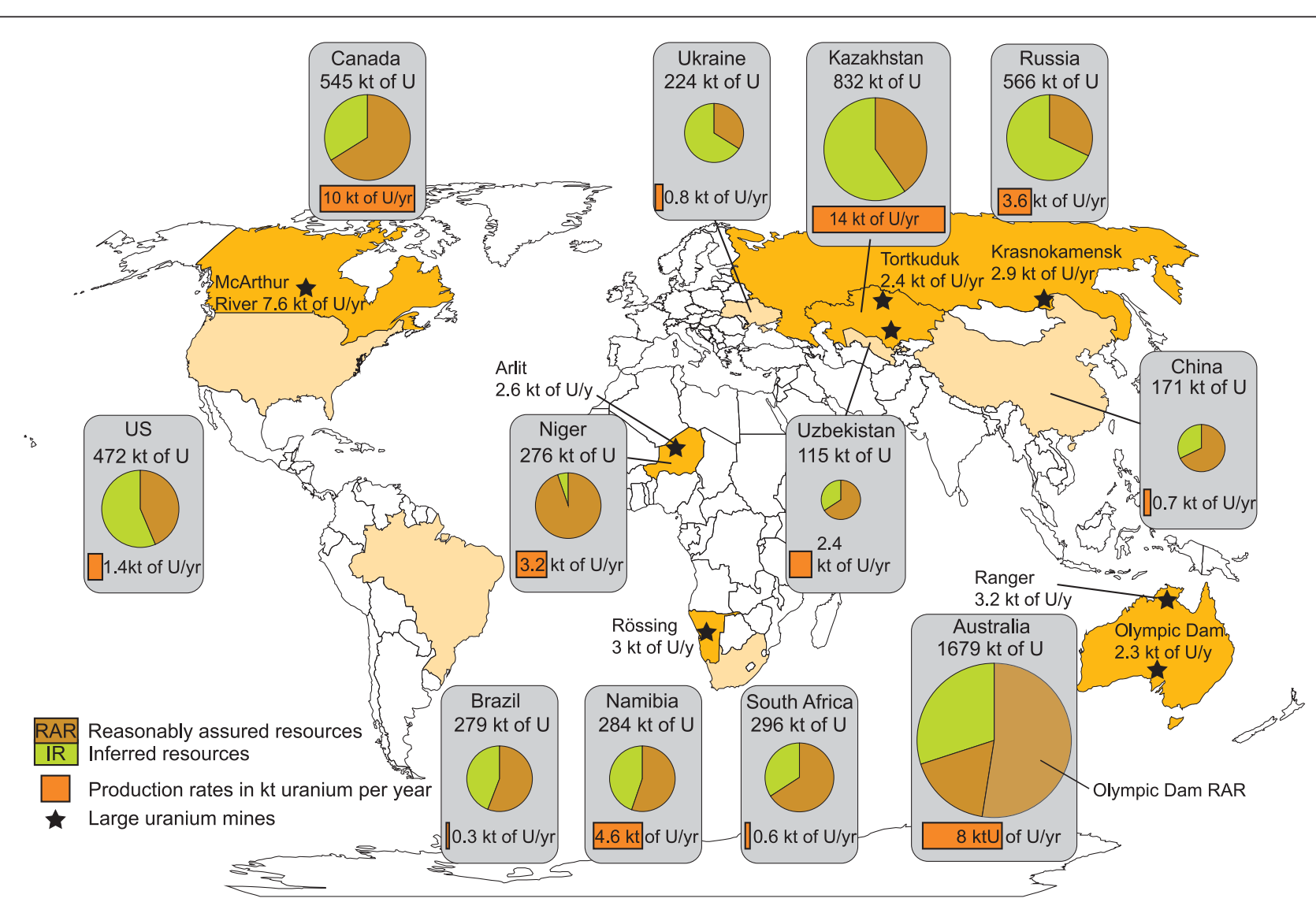

Figure 1. Worldwide distribution of reasonably assured resources (RAR) and inferred resources (IR) in 12 countries in 2009 . These countries together have $90 \%$ of worldwide identified resources and produced $\sim 98 \%$ of the world uranium production of $51 \mathrm{kt}$ of uranium in $2009.4,5$ Whereas Canada and Australia have most of the present resources and active mines, Russia and Kazakhstan have the greatest potential for increased production. This map does not include information on either price or undiscovered resources. 
and $625 \mathrm{kt}$ in IR (2010). ${ }^{6}$ Other deposits are much smaller, some having IR of 100-300 kt of uranium and many more with less than $100 \mathrm{kt}$.

Beyond these identified resources, the Red Book estimates an additional 10,400 kt of uranium in undiscovered resources. Extrapolations concerning the existence of these deposits are based on evidence in known uranium provinces where there is either some direct evidence (prognosticated) or similarities in geologic occurrence (speculative).

In addition, there are unconventional sources of uranium, such as the tailings left behind at gold or uranium mines. Elevated uranium concentrations also occur in phosphate deposits and black shales. Uranium resources in phosphates are estimated to be more extensive than conventional uranium deposits. Extracting uranium as a byproduct of the production of phosphate-based fertilizers could yield up to roughly $10 \mathrm{kt}$ per year, depending on the average ore concentration and world fertilizer demand. Finally, uranium could be extracted from seawater, where it constitutes about 3 ppb by weight, but technological advances are still required to make large-scale extraction economical. ${ }^{7}$

A key issue in estimating the size of a resource is the interplay between the ore grade and the costs of exploration and extraction. The market price of uranium and the exploration activity are strongly correlated (Figure 2). Because increasing price (or more efficient extraction technology) makes it economical to mine lower concentrations, a higher price makes more resources economically attractive, as shown in Table I. The past 40 years of reported uranium resources are summarized in Figure 2. The resource estimates for identified and prognosticated resources have remained constant or increased despite the total cumulative production of $2500 \mathrm{kt}$.

\section{Uranium production and secondary sources of uranium}

During the past 20 years, the amount of uranium mined globally has been less than the global demand for nuclear reactors (Figure 3). Up to $50 \%$ of the demand has been satisfied from

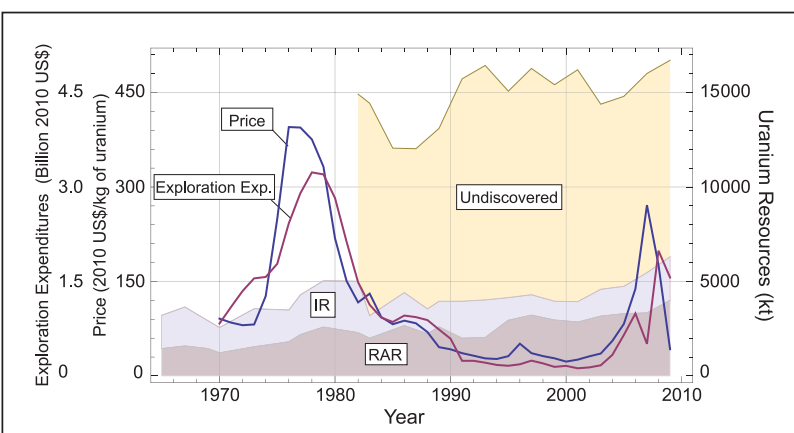

Figure 2. World uranium spot prices and exploration expenditures, as reported in the "Red Book" of the International Atomic Energy Agency (IAEA). ${ }^{4}$ Uranium prices and expenditures are inflation-adjusted and reported in 2010 U.S. dollars. Reported undiscovered resources fluctuated substantially, partly because of the failure of some countries to report. ${ }^{4,8-11}$ stockpiles built up in the 1970s and from secondary sources. The latter include highly enriched uranium (HEU) from nuclear weapons that have been dismantled and blended down for use in reactor fuels as part of the U.S.-Russian Megatons-toMegawatts collaboration. ${ }^{12}$ By the end of 2013, this program will have blended down a total of $500 \mathrm{t}$ of $\operatorname{HEU}\left(>90 \%{ }^{235} \mathrm{U}\right)$ from Russian nuclear weapons to low-enriched reactor-grade fuel. The low-enriched uranium has been used in civilian reactors since 1993, displacing 5-7 kt of natural uranium per year.

Excess plutonium from weapons and separated plutonium from civilian power-production reactors can also be used to fabricate a fuel that is a mixed oxide of uranium and plutonium (MOX). As a rule, roughly $1 \mathrm{t}$ of HEU or separated plutonium will support the operation of a $1 \mathrm{GW}_{\mathrm{e}}$ reactor for one year. The global HEU stockpile of $\sim 1700 t$ and stocks of separated plutonium of $\sim 500 \mathrm{t}$ can provide nuclear fuel for 5-6 years of global demand, assuming the present consumption level. ${ }^{13}$

Another secondary source of uranium is the waste streams from enrichment plants. Depleted uranium, usually regarded as waste, still contains $0.2-0.4 \%{ }^{235} \mathrm{U}$. The world stockpile of $1900 \mathrm{kt}$ of depleted uranium could provide the equivalent of about $500 \mathrm{kt}$ of natural uranium, 7-8 years of today's global demand.

Because of the scheduled end of the Megatons-to-Megawatts program in 2013 and some technical, political, and financial difficulties in mine openings and operations, there have been predictions in the past several years that the strategic gap between supply and demand could increase after 2013. Despite a substantial increase in uranium production between 2003 and 2010 from $35 \mathrm{kt}$ to $53 \mathrm{kt}$, current production is still short of the global demand. Nevertheless, the mining industry has already reacted, and more mining projects or extensions are scheduled to begin operation within the next 5-10 years. ${ }^{4}$ Most current projections now show a probable overproduction of uranium during the next 15 years. ${ }^{4}$ However, a tight supply situation might develop if some of the new projects do not develop as expected, leading to increased uranium prices but also to opportunities for uranium producers with new projects.

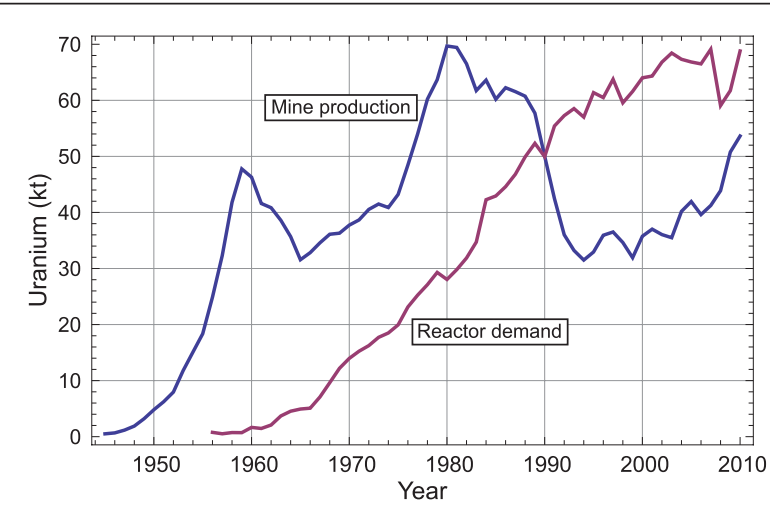

Figure 3. Historical annual uranium production and demand. Because early uranium mining was mainly for military purposes, peak production occurred in the 1970s because of high uranium prices and military needs. ${ }^{10}$ 


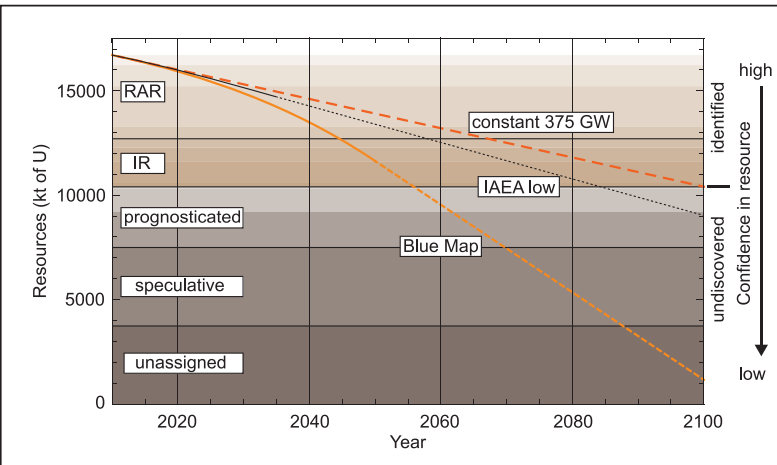

Figure 4. Estimated usage of uranium resources in different categories ${ }^{4}$ according to different scenarios. The solid (orange) line shows the demand for uranium from the International Energy Agency (IEA) BLUE Map scenario. ${ }^{15}$ The dashed (red) line shows the demand for continued use of nuclear power at the current level $\left(375 \mathrm{GW}_{\mathrm{e}}\right.$ ) throughout the 21st century. For comparison, the dotted (black) line shows the IAEA low-demand scenario until $2035 .{ }^{4}$ This plot extends the BLUE Map and the low-demand scenarios to 2100 assuming constant total power generation.

\section{Scenarios for demand and consumption}

Most studies that envision increasing nuclear power to reduce greenhouse gas emissions project a two- to tenfold expansion during the 21 st century, although increases by a factor of two or three are the most that can reasonably be expected by 2050. ${ }^{14}$ As an example, the BLUE Map scenario from the International Energy Agency (IEA) aims to decrease $\mathrm{CO}_{2}$ emissions to $50 \%$ of the 2005 level by 2050 . In this scenario, nuclear power would more than triple, to $1200 \mathrm{GW}_{\mathrm{e}}$, by $2050 .{ }^{15}$ Such an effort could increase the global nuclear share of electricity production to $\sim 24 \%$ by 2050 , contributing $\sim 6 \%$ to the total reduction in global $\mathrm{CO}_{2}$ emissions. In addition to the necessary replacement of the current fleet of reactors, 362 of which will have surpassed a 60-year lifetime by $2050,{ }^{1}$ more than 1000 new reactors would have to be constructed worldwide, a very demanding task.

Based on the IEA BLUE Map scenario, a once-through open cycle would consume all present RAR by 2045 (Figure 4). IR would satisfy demand until 2055, when the annual uranium demand is projected to be about $210 \mathrm{kt} / \mathrm{yr}$. Before this time, substantial uranium resources must be discovered to meet the demand for the rest of the century, even with the projected threefold increase.

Although such projections of future energy utilization are highly speculative, they show that current identified resources by themselves cannot sustain a threefold increase in nuclear power from LWRs. Rather, to satisfy an extrapolated constant demand until 2100 (obtained by extending the BLUE Map scenario beyond 2050), all of today's prognosticated and speculative uranium resources that are projected to cost less than US\$130/kg must be discovered and brought into production, and lower-grade ores must be more efficiently extracted. Changes in the fuel cycle to extend uranium supply can help meet these requirements, but the advantages and disadvantages of each approach must be weighed carefully.

\section{Higher-efficiency nuclear fuel cycles}

To extend uranium resources, fissile nuclides can be reclaimed from spent nuclear fuel (SNF). In addition to the residual ${ }^{235} \mathrm{U}$ in SNF, neutron captures by ${ }^{238} \mathrm{U}$ and subsequent $\beta$-decay create ${ }^{239} \mathrm{Pu}$. Even in present-day LWRs, ${ }^{239} \mathrm{Pu}$ accounts for about onethird of the fission energy produced. Different fuel cycles reflect different strategies for utilizing ${ }^{235} \mathrm{U}$ and ${ }^{239} \mathrm{Pu}$, with important implications for uranium demand.

The once-through open cycle treats SNF as a waste that is directly discarded in a geological repository (Figure 5). This is the present strategy in the United States, Germany, Canada, Finland, and Sweden.

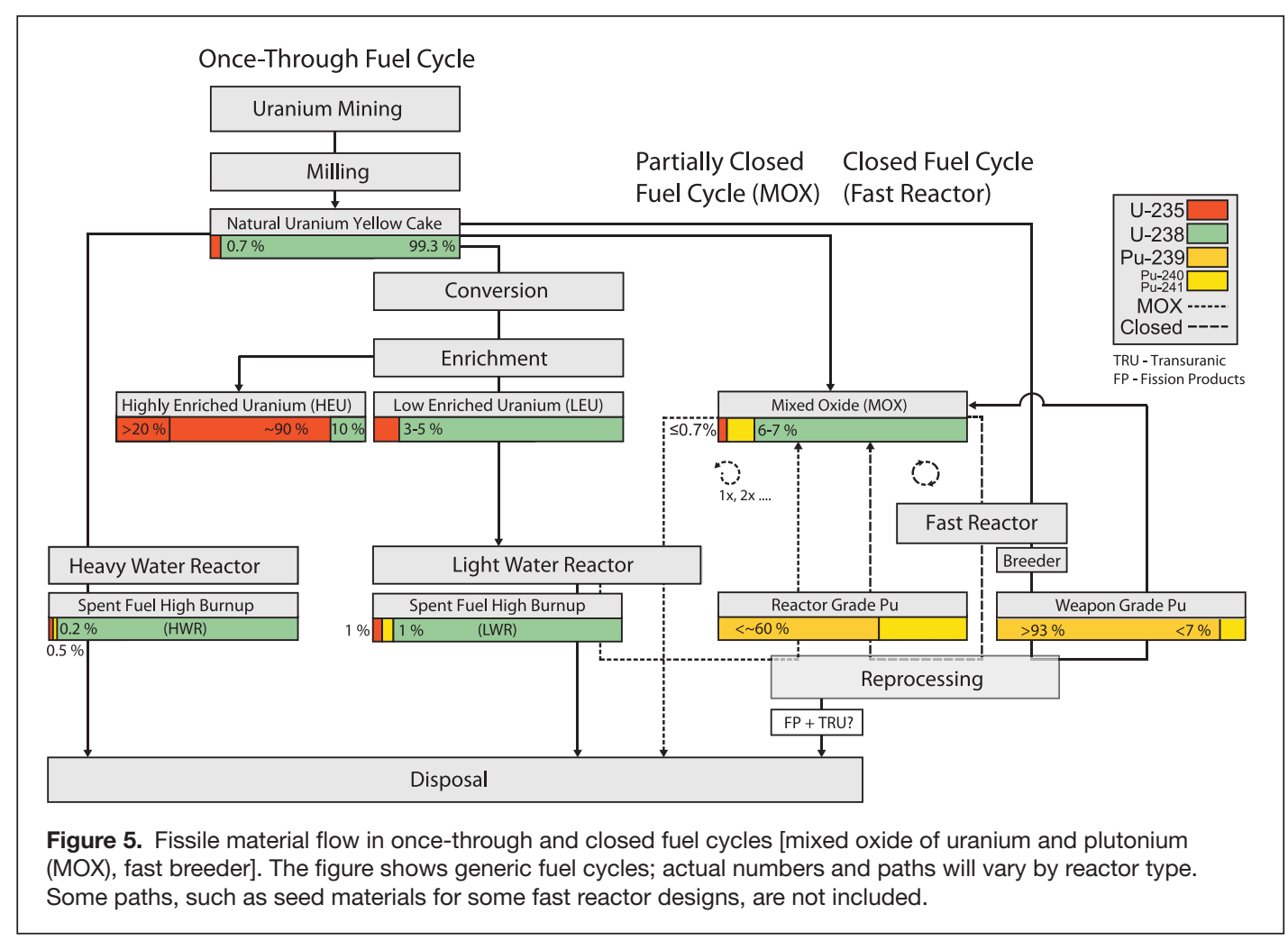


In contrast, France, Japan, and Russia consider the plutonium $(\sim 1$ atom $\%)$ and residual uranium in SNF as a recyclable resource. A closed fuel cycle with reprocessing retrieves approximately $99 \%$ of the fissile nuclides. Reusing reprocessed uranium in fresh fuel reduces an LWR's demand for natural uranium by up to $10 \%$. The separated plutonium can be combined with natural uranium to make MOX, reducing uranium demand by another $15 \% .^{16}$

A detailed analysis ${ }^{17}$ of the cost of reprocessing suggests that an open fuel cycle using LWRs will prevail as long as the price of new uranium fuel is lower than the cost of reprocessing and MOX fuel fabrication. However, several countries (e.g., France, United Kingdom, and Japan) reprocess used civilian fuel. Today, about 30 LWRs in Europe and several in Japan use MOX fuel, accounting for $2 \%$ of the total fuel used per year. ${ }^{18}$

Plutonium can also be used in MOX fuel in fully closed fuel cycles with fast reactors (Figure 5), which use higher-energy (fast) neutrons. A fast "breeder" reactor can be designed that actually produces more fissile material in the SNF than in the original fuel, which allows multiple cycles of reprocessing.

A scarcity of uranium resources would argue for reprocessing to reclaim fissile material. A closed fuel cycle can significantly reduce demand for fresh ore. In the long term, when the new breeder fuel cycle reaches steady state, it could even become almost fissile self-sufficient. ${ }^{19}$ In the near term, uranium savings in a closed fuel cycle depend on the scale and speed of fast reactor deployment and on the number of fissile atoms produced per destruction of a fissile atom (the breeding ratio). According to a recent study performed at the Massachusetts Institute of Technology (MIT), ${ }^{16}$ natural uranium usage could be reduced by $13 \%$ by 2050 and by up to $45 \%$ by 2100 through large-scale deployment of breeder reactors, but such deployment is not expected before 2040. Indeed, no fast breeder reactor has yet been operated commercially. ${ }^{20}$

For both the open and closed fuel cycles, uranium- and thorium-based fuels can be used in other new reactor types, such as advanced heavy-water reactors (AHWRs), supercritical water-cooled reactors (SCWRs), high-temperature gas-cooled reactors (HTGRs) [also called very high-temperature reactors (VHTRs)], and molten salt reactors (MSRs). ${ }^{19}$ However, new fuels, new reactors, and advanced fuel cycles will require considerable resources and experience prior to deployment, so none of these reactors is likely to play a major role in energy production during the next 40 years.

Another method to extend uranium resources is using higher enrichments to more efficiently utilize the fissile ${ }^{235} \mathrm{U}$. The efficiency of fuel use is usually expressed as the "burnup," in gigawatt days per ton of heavy metal (GWd/tHM). Raising the burnup above the 40-50 GWd/tHM that is typical for LWRs could reduce uranium requirements by $4-5 \% .{ }^{21}$ To take advantage of even higher burnup, however, new fuel-assembly materials must be developed to withstand the higher cumulative irradiation. ${ }^{22}$

Another candidate design using high burnup is the travelling wave reactor (TWR), a type of fast reactor. After starting the reactor with a fissile material, fresh natural or even depleted uranium fuel assemblies are inserted and periodically shuffled to breed and burn plutonium in situ. Such a reactor could run for decades without reprocessing or refueling with fissile material.

\section{Environmental impacts of different nuclear fuel cycles}

The selection of a fuel cycle is complicated and depends on each country's environmental, proliferation, economic, and energy policies. ${ }^{23}$ For all fuel cycles, the local environmental impacts of mining directly scale with the uranium consumption. The major issue is the voluminous mine and mill tailings from open pits or underground workings that contain radioactive uranium and thorium decay products, such as ${ }^{222} \mathrm{Rn}$, as well as toxic metals, such as arsenic. Mining techniques used from the 1950 s through the early 1970s led to contamination of near-surface water and soil. ${ }^{24}$ More recently, in situ leaching has been used to dissolve and extract uranium. Mildly oxidizing carbonated water $\left(1 \mathrm{~g} / 1 \mathrm{NH}_{4} \mathrm{HCO}_{3}\right)$ or more aggressive concentrations of sulfuric acid $\left(2-5 \mathrm{~g} / 1 \mathrm{H}_{2} \mathrm{SO}_{4}\right)^{25}$ is circulated through porous, uranium-bearing rock confined between impermeable layers of clay or shale. The fluids are treated at the surface to remove uranium. This technique economically recovers lower concentrations of uranium, and the radioactive decay products remain underground. An important concern, however, is the impact of these circulating fluids on local aquifers. ${ }^{25}$

With regard to nuclear weapons proliferation and nuclear waste disposal, two recent MIT studies compared generic fuel cycles for a two- or threefold global-growth scenario ${ }^{16,26}$ and came to the following conclusions: The once-through cycle followed by direct geological disposal generates the largest volumes of SNF that contains substantial quantities of plutonium. The short-term proliferation risks are reduced because the plutonium is not separated from the SNF and is protected from diversion by the strong radiation generated by fission products. ${ }^{27}$ A closed fuel cycle (MOX with one recycle) generates lower SNF volumes but has similar repository requirements because the vitrified waste releases more heat. Plutonium, which can be viewed as either a source of energy or an environmental hazard, causes acute and long-term health effects upon ingestion or inhalation, ${ }^{28}$ which is an important public health concern.

Any closed fuel cycle will result in the separation of hundreds of tonnes of plutonium, exacerbating existing proliferation concerns. Since plutonium was first isolated in microgram quantities in 1941, more than 2000 t has been created in civilian reactors around the world, generally left in SNF. However, roughly $250 \mathrm{t}$ has been separated from commercially generated SNF. In addition, approximately $70-80 \mathrm{t}$ of new plutonium is added to the global inventory each year, and 10-20 t is separated. Depending on the sophistication of the design, almost all isotopic compositions of separated plutonium are potential weapons material. ${ }^{29}$ A nuclear device can be made with less than $5 \mathrm{~kg}(0.005 \mathrm{t})$ of ${ }^{239} \mathrm{Pu} .{ }^{30}$

The use of fast reactors without breeding can significantly reduce the inventories of plutonium and minor actinides in the final waste stream, transmuting the actinides to shorter-lived 
radionuclides. In this scheme, actinides produced in thermal reactors would be recycled and incorporated into MOX fuels for fast reactors. The amount of plutonium can be further reduced by burning the actinides in inert-matrix fuels (IMFs) that do not contain fertile ${ }^{238} \mathrm{U}$, for example, zirconia $\left(\mathrm{ZrO}_{2}\right) \cdot{ }^{31,32}$ Reactors would probably use a mixture of MOX and IMF, and irradiation would substantially reduce the plutonium and minor actinide contents of the IMF. ${ }^{33} \mathrm{ZrO}_{2}$ is recognized as a durable, radiationresistant waste form for direct disposal. ${ }^{34}$

\section{Thorium fuel cycle and resources}

Thorium, although itself not fissile, is an alternative to uranium as a nuclear fuel. Specifically, through neutron capture and subsequent $\beta$-decay reactions, ${ }^{232} \mathrm{Th}$ is transmuted to fissile ${ }^{233} \mathrm{U}$, in the same way that ${ }^{239} \mathrm{Pu}$ is created from ${ }^{238} \mathrm{U}$.

Thorium has only one naturally occurring isotope, ${ }^{232} \mathrm{Th}$, but is three times more abundant in Earth's crust than uranium. However, thorium is less often concentrated into economical ore deposits, because there are few geochemical processes for its concentration.

\section{Thorium resource estimates}

Figure 6 shows the distribution of identified thorium resources by country and type of deposit. In all countries, for a cost below US $\$ 80 / \mathrm{kg}$, there are $829 \mathrm{kt}$ of RAR and $1400 \mathrm{kt}$ of IR, with another $1387 \mathrm{kt}$ in prognosticated resources. Information on thorium reserves is limited (just one of the Red Book's 457 pages), ${ }^{4}$ and some of the data are more than 20 years old, ${ }^{10}$ so estimates are much less certain than for uranium. Nevertheless, Australia, Brazil, India, the United States, and Venezuela have significant identified resources of thorium, of between 300 and $450 \mathrm{kt}^{4}$

Because the current market for thorium is modest, it is produced only as a byproduct of rare-earth (RE) recovery, largely from monazite $\left(\mathrm{CePO}_{4}\right)$. This mineral contains an average of $8-10 \mathrm{wt} \%$ thorium, so its processing theoretically recovers 500-740 t of thorium metal per year worldwide. ${ }^{36}$ Some countries, such as India, stockpile this excess inventory for future nuclear fuel applications, whereas others dispose of it. For example, the United States disposed of 3220 t of thorium nitrate as low-level radioactive waste at the Nevada Test Site in $2005 .{ }^{37}$ Thorium disposal costs are partially responsible for the decrease in the production of REs in the United States. If the thorium were instead used in a nuclear fuel cycle, it would limit the need for expensive disposal. ${ }^{36,38}$

Because of the modest market for thorium, there has been little incentive to explore for new deposits or to survey known deposits. Most resources have been discovered and evaluated during exploration for uranium and REs. If thorium were exploited for commercial nuclear fuel applications, the minerals bastnaesite $\left[(\mathrm{Ce}, \mathrm{Th}, \mathrm{La}, \mathrm{Y}, \mathrm{Ca}) \mathrm{CO}_{3} \mathrm{~F}\right]$ and thorite $\left(\mathrm{ThSiO}_{4}\right)$, which have higher thorium contents, would likely be exploited. ${ }^{35}$

\section{Thorium fuel cycle}

Any thorium fuel cycle will need a neutron source, such as fission of ${ }^{239} \mathrm{Pu}$ or ${ }^{235} \mathrm{U}$ to breed fissile ${ }^{233} \mathrm{U}$ from ${ }^{232} \mathrm{Th}$. Reactors

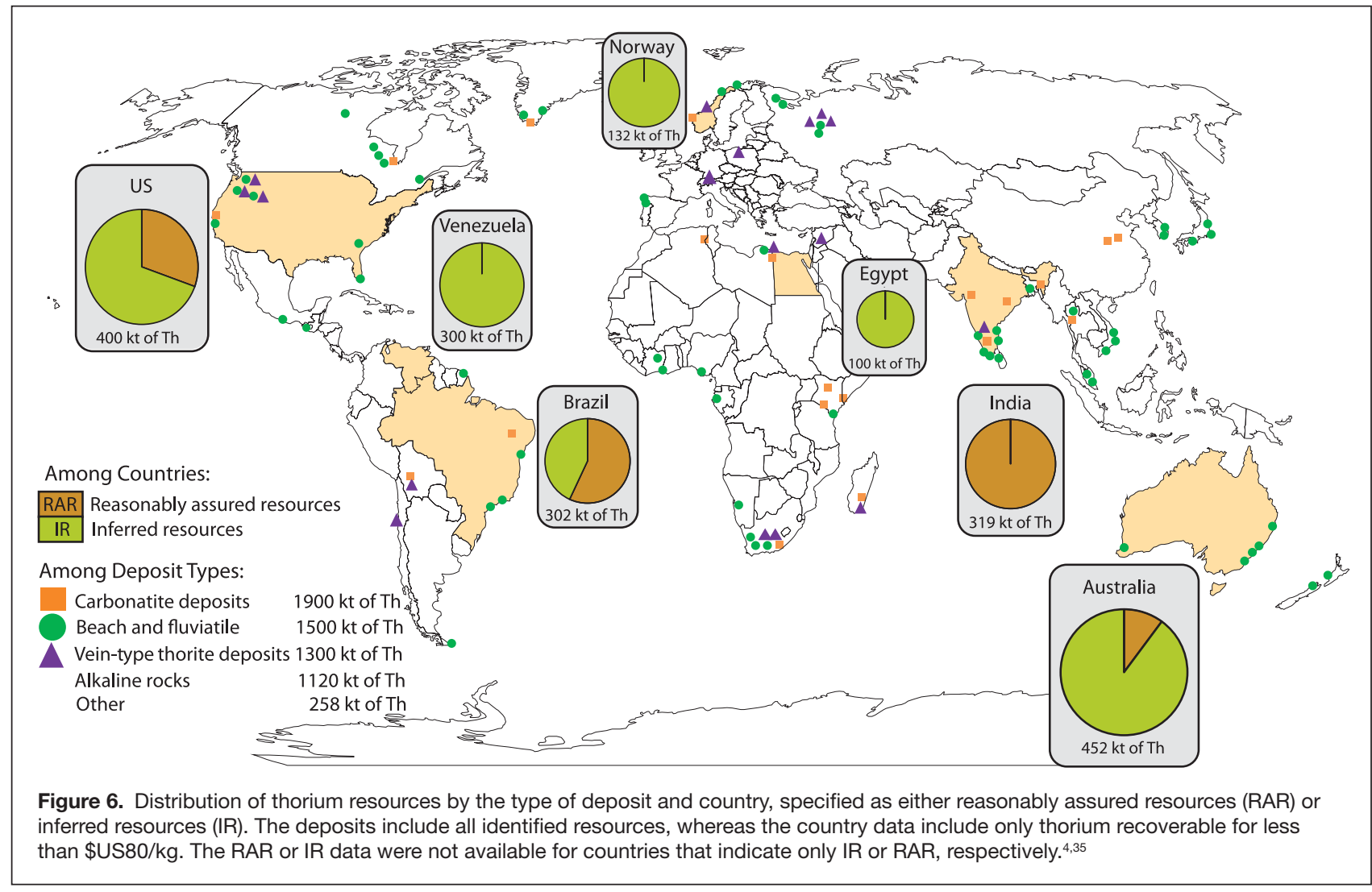


and fuel cycles using thorium have been investigated since the 1950s. From the mid-1950s to the mid-1970s, several experimental and prototype reactors were operated. However, thorium fuels and fuel cycles have not received the attention required for their development because uranium reserves have thus far been judged to be adequate for the uranium/ plutonium fuel cycle. A fuel cycle that reduces uranium demand is most important to countries with extensive thorium resources. India and China are actively developing the thorium fuel-cycle technology.

Like uranium, thorium can be used in either an open oncethrough cycle or a closed fuel cycle with reprocessing to reclaim the fissile ${ }^{233} \mathrm{U}$. In an open fuel cycle using LWRs, ${ }^{235} \mathrm{U}$ or ${ }^{239} \mathrm{Pu}$ can be used as a neutron source to generate ${ }^{233} \mathrm{U}$ from ${ }^{232} \mathrm{Th}$. Because the nuclear reactions build up ${ }^{233} \mathrm{U}$, less ${ }^{235} \mathrm{U}$ is needed during burnup. One simple fuel is a homogeneous 3:1 mixture of thorium and enriched uranium $\left(20 \%{ }^{235} \mathrm{U}\right) .{ }^{16,39}$ A more efficient approach involves the use of a heterogeneous fuel, in which either the core of a fuel assembly or even each fuel pin is a uranium "seed" of $20 \%$ enriched ${ }^{235} \mathrm{U}$ surrounded by a (Th, $\mathrm{U}_{2} \mathrm{O}_{2}$ "blanket."

A preliminary reference design using heterogeneous thorium fuel assemblies is the Radkowsky Thorium Reactor (RTR), proposed for the Russian VVER-1000 pressurized water reactor (PWR). This design would consume 20\% less natural uranium than using standard uranium fuel and was shown to be economically feasible. ${ }^{40}$ The RTR is more proliferation-resistant than an LWR, because it produces $80 \%$ less plutonium with an isotopic mixture that is less usable for weapons.

For the initial neutron investment of thorium-based fuels to break even with those of uranium-based fuels, a burnup of more than $100 \mathrm{GWd} / \mathrm{tHM}$, more than double that typical for LWRs, will be required. ${ }^{16}$ A major challenge for thorium-based fuels is that new materials would have to be developed to withstand long irradiation times, just as for high-burnup uranium/plutonium fuel cycles.

One early study of thorium-recycling options in a closed fuel cycle compared resource utilization of various reactor fuel cycles in the Canadian heavy-water (CANDU) reactors. The thorium cycles considered only homogeneous fuel whose initial fissile material was either ${ }^{235} \mathrm{U}$ or $\mathrm{Pu}$ and assumed that ${ }^{233} \mathrm{U}$ and remaining fissile materials were recycled from the SNF whereas new fissile material was added to maintain burnup. At steady state, the analysis found a savings of up to $90 \%$ in natural-uranium usage compared with a once-through fueling with natural uranium. ${ }^{35}$

India has greater thorium than uranium resources, which has led to a unique nuclear strategy employing (1) uraniumfueled pressurized heavy-water reactors (PHWRs) that produce plutonium, (2) plutonium-fueled fast breeder reactors (FBRs) that breed ${ }^{239} \mathrm{Pu}$ and ${ }^{233} \mathrm{U}$, and (3) AHWRs that will enable a selfsustained ${ }^{232} \mathrm{Th}-/ 233 \mathrm{U}$-based fuel cycle and obtain $65 \%$ of their power from thorium. ${ }^{41}$ Full commercialization of the AHWRs is not expected before $2030 .{ }^{42}$
Although a thorium-based fuel cycle produces no plutonium, fissile ${ }^{233} \mathrm{U}$ bred from ${ }^{232} \mathrm{Th}$ is still very attractive for weapons purposes. However, accumulation of other radioactive isotopes, notably ${ }^{212} \mathrm{Bi}$, which is a daughter product of ${ }^{232} \mathrm{U}$, and gammaemitting ${ }^{208} \mathrm{Tl}$, which accumulates during irradiation of ${ }^{232} \mathrm{Th}$, increase proliferation resistance. ${ }^{43}$

\section{Conclusions}

Identified uranium resources can sustain the present scale of nuclear energy production until the end of the 21 st century. However, pursuing a two- to threefold increase in nuclear power generation would require development of presently undiscovered uranium resources, both prognosticated and speculative. Even with such a tripling of nuclear power generation, the reduction of $\mathrm{CO}_{2}$ emissions would be modest, some $6 \%$ as compared to the reductions that are required for limiting atmospheric $\mathrm{CO}_{2}$ levels to no more than twice preindustrial levels by $2050 .^{15}$

Uranium resources can be extended to a certain extent for either open or closed fuel cycles. For closed fuel cycles, fissile nuclides, ${ }^{235} \mathrm{U}$ and ${ }^{239} \mathrm{Pu}$, can be reclaimed and utilized in MOX fuel or IMF in current LWRs. More efficient utilization of fissile actinides can be attained by the use of advanced fast reactors that employ higher-energy neutrons. However, closed fuel cycles with reprocessing pose the risk of diversion of fissile material to weapons production. Whether one follows a strategy of direct disposal of spent nuclear fuel or reprocessing and some combination of LWRs or advanced reactors, geologic disposal of used nuclear fuel and/or highly radioactive waste is always required. Present uranium resources are large enough that the development of new nuclear fuel cycle strategies is not immediately required.

The thorium fuel cycle offers some enhancements for expansion of nuclear power generation. Nuclear fuels that use both uranium and thorium can extend the resources available to support nuclear power production. In addition, the thorium/ uranium fuel cycle has some advantages over the plutonium/ uranium fuel cycle in terms of geologic disposal. As an example, thorium-based fuels are remarkably durable, because of the single oxidation state of thorium, and could be disposed of in a number of different types of geology. For some countries with substantial thorium resources, the thorium fuel cycle might be a viable option. However, few countries actively develop this technology, and as long as natural uranium is not scarce, it is unlikely that a thorium-based fuel cycle will be implemented on a global scale.

\section{Acknowledgments}

M.E. and R.C.E. thank the Center for International Security and Cooperation (CISAC), part of the Freeman Spogli Institute for International Studies, Stanford University, where they were both guest scholars during the preparation of this article. Financial support came from an institutional grant to CISAC from The John D. and Catherine T. MacArthur Foundation. 


\section{References}

1. Power Reactor Information System (PRIS): Latest News Related to PRIS and the Status of Nuclear Power Plants (International Atomic Energy Agency, Vienna, Austria, 2011), www.iaea.org/programmes/a2 (accessed May 17, 2011).

2. World Energy Outlook 2010 (Organisation for Economic Co-operation and Development, Paris, France, 2010).

3. World Nuclear Power Reactors \& Uranium Production (World Nuclear Association, London, 2011), www.world-nuclear.org/info/reactors.html (accessed September 2011)

4. Uranium 2009: Resources, Production and Demand (NEA Report No. 6891, Organisation for Economic Co-operation and Development, Paris, France, 2010). 5. World Uranium Mining (World Nuclear Association, London, 2010), www. world-nuclear.org/info/inf23.html (accessed September 2011).

6. Our Strategy Delivers, Annual Report 2010 (BHP Billiton, Melbourne, Victoria, Australia, 2010).

7. A.M. MacFarlane, M. Miller, Elements 3, 185 (2007).

8. Uranium 2005: Resources, Production and Demand (NEA Report No. 6098, Organisation for Economic Co-operation and Development, Paris, France, 2006). 9. Uranium 2007: Resources, Production and Demand (NEA Report No. 6345, Organisation for Economic Co-operation and Development, Paris, France, 2008). 10. Forty Years of Uranium Resources, Production and Demand in Perspective (NEA Report No. 6096, Organisation for Economic Co-operation and Development, Paris, France, 2006).

11. ESA average uranium prices for 2009 (Euratom, Luxembourg, 2011), http:// ec.europa.eu/euratom/observatory price.html (accessed June 2011).

12. J.P. Timbie, Sci. Global Secur. 12, 165 (2004).

13. Global Fissile Material Report 2010. Balancing the Books: Production and Stocks (International Panel on Fissile Materials, Princeton, NJ, 2010).

14. Energy, Electricity and Nuclear Power Estimates for the Period up to 2050 (Report IAEA-RDS-1/30, International Atomic Energy Agency, Vienna, Austria, 2010).

15. Energy Technology Perspectives 2010: Scenarios \& Strategies to 2050 (International Energy Agency, Paris, France, 2010).

16. M. Kazimi, E.J. Moniz, C.W. Forsberg, S. Ansolabehere, J.M. Deutch, M.J. Driscoll, M.W. Golay, A.C. Kadak, J.E. Parsons, M. Regalbuto, G. Apostolakis, P. Hejzlar, E. Shwageraus, The Future of the Nuclear Fuel Cycle (Massachusetts Institute of Technology, Cambridge, MA, 2011).

17. M. Bunn, S. Fetter, J.P. Holdren, B. van der Zwaan, The Economics of Reprocessing vs. Direct Disposal of Spent Nuclear Fuel (Project on Managing the Atom, Final Report DE-FG26-99FT4028, Harvard University, Cambridge, MA, 2003).

18. "Mixed Oxide (MOX) Fuel" (World Nuclear Association, London, 2011), www. world-nuclear.org/info/inf29.html (accessed January 2012).

19. C. Forsberg, D. Wade, A. Bement, C. Boardman, B. Boullis, D. Crawford, K. Fukada, J.P. Glatz, D. Greneche, W. Halsey, J.S. Herring, M. Leroy, D. Lewis, H. Noda, P. Peterson, L. van den Durpel, M.S. Yang, A. Caponiti, B.J. Garrick, H. Khalil, A. Moisseysev, J.M. Ryskamp, Generation IV Roadmap Fuel Cycle Assessment Report [Report GIF-014-00, U.S. Department of Energy Nuclear Energy Research Advisory Committee (NERAC) and Generation IV International Forum (GIF), Paris, France, 2002].
20. T.B. Cochran, H.A. Feiveson, W. Patterson, G. Pshakin, M.V. Ramana, M. Schneider, T. Suzuki, F. von Hippel, Fast Breeder Reactor Programs: History and Status (Research Report 8, International Panel on Fissile Materials, Princeton, NJ, 2008).

21. Very High Burn-ups in Light Water Reactors (NEA Report No. 6224 , Organisation for Economic Co-operation and Development, Paris, France, 2006). 22. T.K. Kim, T.A. Taiwo, Fuel Cycle Analysis of Once-Through Nuclear Systems (Report ANL-FCRD-308, ANL, Argonne, IL, 2010).

23. R.C. Ewing, W. Runde, T.E. Albrecht-Schmitt, MRS Bull. 35, 859 (2010).

24. A. Abdelouas, Elements 2, 335 (2006).

25. Uranium Extraction Technologies (Technical Reports Series No. 359, International Atomic Energy Agency, Vienna, Austria, 1993).

26. S. Ansolabehere, J. Deutch, M. Driscoll, P.E. Gray, J.P. Holdren, P.L. Joskow, R.K. Lester, E.J. Moniz, N.E. Todreas, E.S. Beckjord, The Future of Nuclear Power (Massachusetts Institute of Technology, Cambridge, MA, 2003).

27. Management and Disposition of Excess Weapons Plutonium (National Academies Press, Washington, DC, 1994).

28. W.G. Sutcliffe, R.H. Condit, W.G. Mansfield, D.S. Myers, D.W. Layton, P.W. Murphy, A Perspective on the Dangers of Plutonium (Report UCRL-JC-118825, Lawrence Livermore National Laboratory, Livermore, CA, 1995).

29. C.G. Bathke, R.K. Wallace, J.R. Ireland, M.W. Johnson, K.S. Bradley, B.B. Ebbinghaus, H.A. Manini, B.W. Smith, A.W. Prichard, paper presented at the 8th International Conference on Facility Operations: Safeguards Interface (sponsored by the American Nuclear Society), Portland, OR, March 30-April 4, 2008.

30. J.C. Mark, Sci. Global Secur. 4, 111 (1993).

31. P.G. Boczar, M.J.N. Gagnon, P.S.W. Chan, R.J. Ellis, R.A. Verrall, A.R. Dastur, Can. Nucl. Soc. Bull. 18, 2 (1997).

32. V.M. Oversby, C.C. McPheeters, C. Degueldre, J.M. Paratte, J. Nucl. Mater. 245, 17 (1997)

33. C. Pistner, W. Liebert, F. Fujara, J. Nucl. Mater. 352, 268 (2006).

34. W.L. Gong, W. Lutze, R.C. Ewing, J. Nucl. Mater. 277, 239 (2000).

35. Thorium Fuel Cycle-Potential Benefits and Challenges (IAEA-TECDOC-1450, International Atomic Energy Agency, Vienna, Austria, 2005).

36. J.B. Hedrick, "Thorium," in 2007 Minerals Yearbook (U.S. Geological Survey, Washington, DC, 2008), chap. 76.

37. J.B. Hedrick, "Rare Earths," in 2004 Minerals Yearbook (U.S. Geological Survey, Washington, DC, 2005), chap. 60.

38. R. Jaffe, J. Price, G. Ceder, R. Eggert, T. Graedel, K. Gschneidner, M. Hitzman, F. Houle, A. Hurd, R. Kelley, A. King, D. Milliron, B. Skinner, F. Slakey, Energy Critical Elements: Securing Materials for Emerging Technologies (Materials Research Society/American Physical Society, Washington, DC, 2011).

39. A. Galperin, E. Shwageraus, M. Todosow, Nucl. Technol. 138, 111 (2002). 40. A. Galperin, P. Reichert, A. Radkowsky, Sci. Global Secur. 6, 265 (1997).

41. D.J. Cordier, "Thorium," in 2008 Minerals Yearbook (U.S. Geological Survey, Washington, DC, 2010), chap. 76 .

42. A. Kakodkar, Statement by Dr Anil Kakodkar, Chairman of the Atomic Energy Commission and leader of the Indian delegation, International Atomic Energy Agency 53rd General Conference, Vienna, Austria, September 16, 2009; http://www iaea.org/About/Policy/GC/GC53/Statements/india.pdf (accessed September 2011). 43. J. Kang, F.N. von Hippel, Sci. Global Secur. 9, 1 (2001)

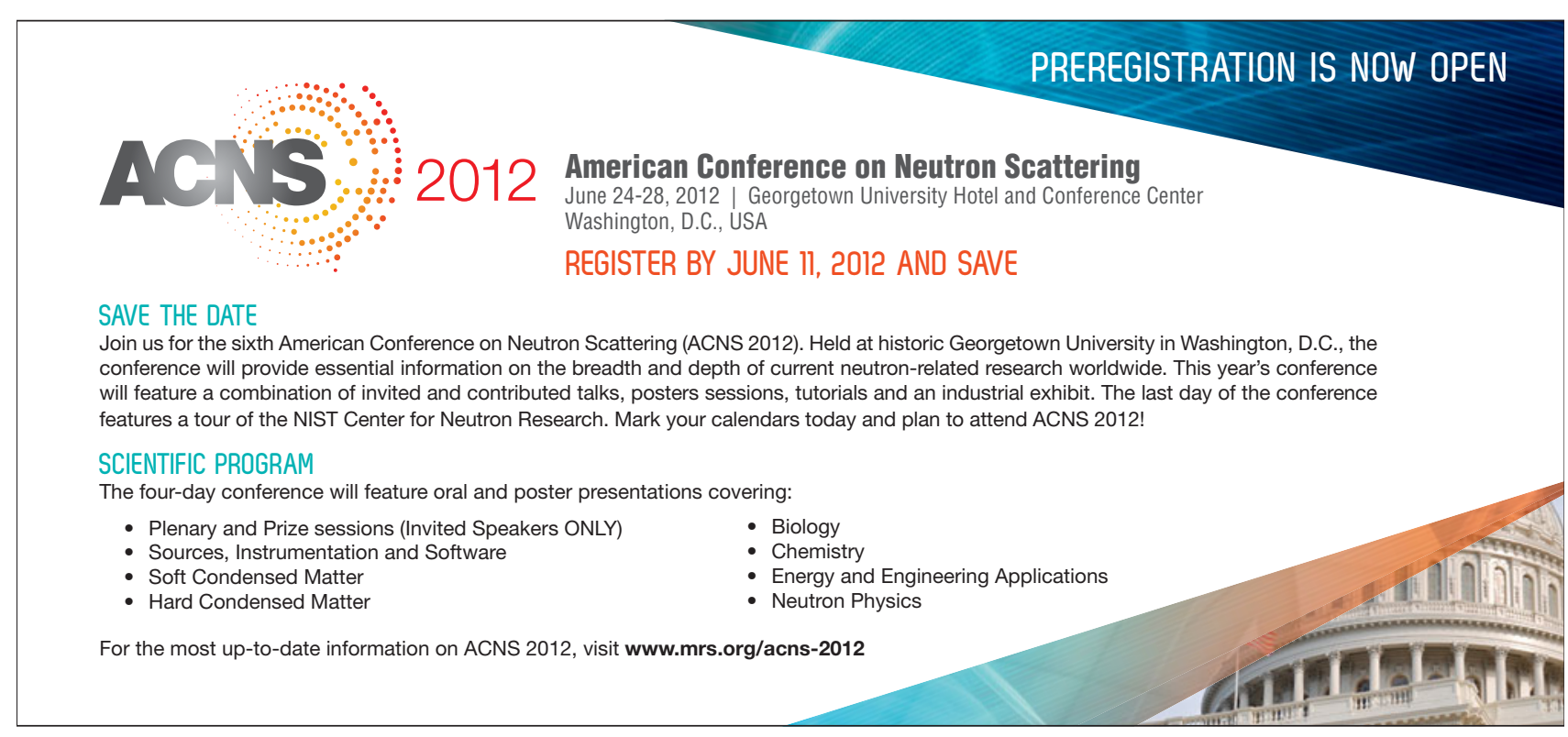

